\title{
Constructive and Technical Aspects of Career Decision Making for Senior Secondary Students
}

\author{
Ranbir Singh ${ }^{1}$, Dr. Gagandeep Jagdev ${ }^{2 *}$ \\ ${ }^{I}$ Research Scholar (Ph.D), Guru Gobind Singh College of Education, Guru Kashi University, Talwandi Sabo \\ $(P B)$. India. \\ ${ }^{2}$ Dept. of Comp. Science, Punjabi University Guru Kashi College, Damdama Sahib (PB). India.
}

\author{
*Corresponding Author: Dr. Gagandeep Jagdev, Dept. of Comp. Science, Punjabi University Guru Kashi \\ College, Damdama Sahib (PB). India.
}

\begin{abstract}
Career decision making remains the key aspect for the senior secondary school students since years. Career decision making is influenced by many factors. Proper career guidance and counseling programs enables students to make more informed and better decisions in respect with their career decisions. Today everyone is aware of the role played by good education in shaping individual's career. Information and communication technologies are converting career information and guidance services, just as they are renovating service delivery in other sectors (e.g. banking and health services).Technology and education is advancing itself at a very high pace. The technology invented today becomes old tomorrow. Our educational institutes like universities and colleges have a responsibility to prepare learners to take advantage of the latest tools and techniques to help them tackle complex problems. In this research paper we will explore the role played by different parameters like geographical location, stream, gender, and education in career decision making of senior secondary students. The first challenge is on the part of teachers. It is prime responsibility of the teachers to integrate new technologies into their classrooms, but due to lack of adequate and ongoing professional development they themselves are unprepared or unable to understand new technologies. Secondly it is found that teachers have a mindset that technological experiment is outside the scope of their job descriptions. Their teaching is restricted to the defined syllabus and not beyond it. Rigid lecture-and-test models of learning are failing to challenge students to experiment and engage in informal learning. Opportunities for such informal learning can be found in non-traditional classroom models, such as flipped classrooms, which allow for a blending of formal and informal learning. There are teachers that are looking for the need of personalized learning, but they aren't given the tools they need to accomplish it, or adequate tools simply don't exist.
\end{abstract}

Keywords: Career decision making; education; senior secondary school.

\section{INTRODUCTION}

Career guidance plays a key role in helping senior secondary school students and education systems to meet their goals. It also promotes equity: recent evidence suggests that social mobility relies on wider acquisition not just of knowledge and skills, but of an understanding about how to use them. In this context, the mission of career guidance is widening, to become part of lifelong learning $[1,2]$. Fig. 1 details different phases involved in career decision making. Already, services are starting to adapt, departing from a traditional model of a psychology-led occupation interviewing students about to leave school. One key challenge for this changing service is to move from helping students decide on a job or a course, to the broader development of career management skills. For schools, this means building career education into the curriculum and linking it to students' overall development. A number of countries have integrated it into school subjects. However, career education remains concentrated around the end of compulsory schooling. In upper secondary and tertiary education, services focus on immediate choices rather than personal development and wider decision making, although this too is starting to change in some countries. A second challenge is to make career guidance more widely available throughout adulthood. Such provision is underdeveloped, and used mainly by unemployed people accessing public employment services. Some new services are being linked to adult education institutions, but these are not always capable of offering wide and impartial 
advice. Efforts to create private markets have enjoyed limited success, yet public provision lacks sufficient funding. Thus creation of career services capable of serving all adults remains a daunting task. Web-based services may help with supply, but these cannot fully substitute for tailored help to individuals [3, 4, and 14].

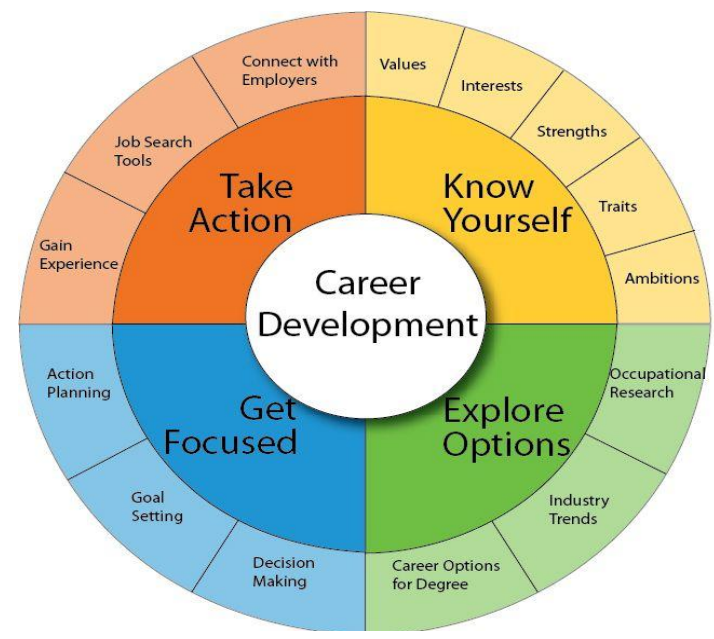

Fig1. The figure depicts different phases involved in career decision making

College and career guidance and counseling programs aim to help students make more informed and better educational and career choices [5]. Among other things, programs offer information on high school course offerings, career options, the type of academic and occupational training needed to succeed in the workplace, and postsecondary opportunities that are associated with their field of interest. Programs also often provide teachers, administrators, and parents with information they can use to support students' career exploration and postsecondary educational opportunities $[6,14,15]$.

- Activities associated with career guidance and counseling programs typically include:

- Advising students and parents on high school programs and academic curriculum, preparing them for college application and admission.

- Arranging dual/concurrent enrollment and Advanced Placement credits to prepare students for the rigor of postsecondary education.

- Planning and preparation for college admissions tests.

- Informing students about postsecondary financing that can be used to support advanced education and training.

- Developing career portfolios, which include test and grades results, examples of student work, and resumes and cover letters to prospective employers.

- Arranging job shadowing, work placements, and community-based learning programs to allow students to directly experience workplace situations.

- Sponsoring workshops, classes, focus groups, and special presentations that focus on job skills and personal development.

- Providing specialized counseling and intervention services to provide students with individualized attention.

\section{ANALYSIS AND EVALUATION}

A good preparation for senior secondary school students is to sit down and analyze their goals as well as their activities, no matter whether they have decided their respective field of study. The emphasis should be laid on below mentioned facts [7, 8, 14, and 16].

- academic and personal strengths and weaknesses

- extracurricular activities

- awards 
- grade point average (GPA)

- class rank

- AP scores

Next, senior school students should think about and list the qualities they're looking for in a college, do they want to go away to school, stay close to home, or take online courses. Guidebooks, the Internet, and counselors at school are particularly helpful resources.

\subsection{Developing Decision Making Skills in High School Students}

Decision making is something we do every minute of the day. Decision making skills and its related problem solving skills are one of the 5 major types of life skills identified by the World Health Organization as essential for development of an individual.

\subsection{Informed Decisions}

For most of us, the small decisions that we make every day, such as the clothes we wear, the shows that we want to watch on TV, the food we choose to eat, can generally be made without much thought. However, when it comes to making major decisions, such as, selecting a career or choosing a university, having a step by step approach to decision making, with the correct information at hand, allows us to make informed decisions.

\subsection{Knowledge is Power}

Knowledge means having completed and correct information about a particular item. Having such knowledge is key to the decision making process and the ability to collect and analyze information is a vital part of the decision making skills to be acquired. There are a number of ways that we can acquire knowledge which includes:

- Observation

- Experience

- Reasoning

- Logic

- Modelling

- Testimony

- Feedback

- Brainstorm

- Authority

- Intuition

\section{Decision Making Process}

The steps required for decision making are shown in Fig. 2 and elaborated as under [9, 10, 14\&15].

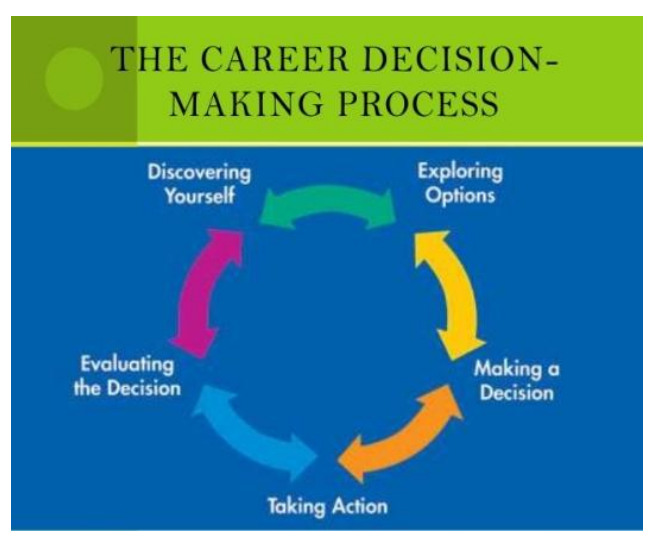

Fig2. Figure shows the steps involved in career decision making process

- Firstly, the subject matter regarding which decision is to be made should be clear. 
- Secondly, recognize the number of choices that may be taken in respect of the decision.

- Third is to deeply analyze the benefits, risks, opportunities and threats involved in case of each available option.

- Selection should be made on the basis of informed knowledge, an appropriate option or solution.

- Next is to implement the chosen option or solution.

- Deeply review and evaluate influence of decision.

- Finally, modification should be done in the course of action, if required.

\subsection{Defining the Subject Matter}

Frequently, the subject matter is effortlessly defined as it is understandable. In several cases, the subject matter comprises a series of categories of dependencies or items with each requiring a decision to be made. For instance, the decision regarding which course should be studied at university by the senior secondary school student requires him/her to make certain additional decisions like what should be the chosen career, which university is most suitable for the concerned student, what are the courses offered by the university and so on. Here, the need is to break down the subject matter into its categories of items and have the decision making process applied into each dependency or category.

\subsection{Identification of available options}

The decision making process involves to identify the available options to make an appropriate decision which further demands knowledge. The knowledge can be acquired using appropriate means. The technique to be used depends on the decision to be made. Making a career choice is very critical and includes using different techniques to acquire knowledge mentioned as under [11, 14, and 16].

- Taking guidance from one who bears experience in that particular career (testimony).

- To review different articles on websites concerned with career guidance (authority).

- Restraining options to a select few based likes and dislikes (reasoning).

\subsection{Analyzing risks, threats, benefits, and opportunities}

There are several approaches to analyze risks and opportunities like decision tree or a decision matrix or mind map.

\subsection{Select appropriate option or solution}

After analyzing benefits and risks involved, the next phase is of making decision. Unlike individuals, the cases which involve a group of individuals in decision making process, the final decision is reached by consensus, such as committee, team or council.

\subsection{Implementing chosen solution or option}

Depending on the concerned subject matter and the threats involved, the implementation of the solution can be made in stages or at once. If a sequence of decisions is needed, then it is better to follow a course of action in making decisions rather at once. For instance, opting for a course to be studied at university after school [12,14, and 16].

\subsection{Reviewing and accessing the impact of the made decision}

Ideally, one would have projected the influence of any decisions made after having applied steps 1 to 5. In some circumstances however, unanticipated significances may happen or if they were predicted, the concerns may be further severe than predicted.

\subsection{Modification in the course of action if required}

An operative risk management technique is to implant into the decision making process an iterative tactic to the application step. "Iterative" means applying the process repeatedly and allows more elasticity in the decision making process. A final decision may therefore only be made over a period of time with adjustments made to the short-term decision or parts of the decision along the way, if necessary, after acquiring more knowledge (such as collecting feedback) $[13,14,16]$. 


\section{QUESTIONNAIRE FOR SENIOR SECONDARY SCHOOL STUDENTS}

The following is the questionnaire prepared for senior secondary school students to analyze the trend among them after passing out the school.

- Do you feel concerned for your future job?

- Do you have any kind of fear regarding your future job?

- Are you confident regarding opting for a particular profession in your life?

- Do your parental occupations influence you in deciding your future job?

- Do you feel that you need any kind of assistance in deciding your future job?

- Do you feel confused in deciding your future job?

- Are there any complicated problems that resist you from deciding your future job?

- Do you get environment in your school that would help in your career decision making?

- Are getting good grades in school a necessity for succeeding in your future job?

- Are you confirmed about the subjects in whom you have strong hold?

- Are you well aware of the streams relevant to the subjects you are interested in?

- How much influence does school knowledge have in deciding your future job?

- Do you have any idol that influences in making decision regarding your career?

- Do you focus on your future job in spare time?

- Do your school organizes any kind of workshops, seminars etc. which would assist in your future career decision making?

- Are you aware of the places or locations relevant to your future job?

- Do you have a valid reason to justify your choice regarding career decision making?

- Do you have any other friends of yours having the same future job plan as yours?

- Do you think that your future job selection can help you to solve hard life problems?

- Will your future job selection upgrade society?

- Are you well focused where to invest in accordance with compliance of your future job?

- Do your parents education level impacted your career decision making?

- Can any kind of complication in future force you to change your future job plan?

- Do markets influence your career decision making option?

- Are you interested in going abroad to accomplish your future job plans?

- Are you willing to indulge in any anti-social activity to fulfill your future job plans?

\section{CONCLUSION}

The research paper focused on specific personality traits responsible for influencing career maturity. This originates the need for teachers and guardians to include personality assessment in career counseling to gain insight of student's strengths and weaknesses. For instance, a student low on openness could be steered towards a more active investigation of career options. The absence of indepth survey relevant to career options may mislead students. The role of parental influence on career decision has significant impact on student's choice in finalizing his/her career.

\section{REFERENCES}

[1] Bounds, P. S., Washington, A. R., \& Henfield, M. S. (2013). Individuals and families of African descent. In B. T. Erford \& D. G. Hays, (Eds.), Developing multicultural counseling competence: A systems approach (2nd ed.). Upper Saddle River, NJ: Pearson. 
[2] Brown, D. (2011). Career information, career counseling, and career development (10 ${ }^{\text {th }}$ ed.). Boston: Pearson.

[3] Bullock-Yowell, E., Andrews, L., \& Buzzetta, M. E. (2011). Explaining career decision making selfefficacy: Personality, cognitions, and cultural mistrust. The Career Development Quarterly, 59, 400-411.

[4] Cokley, K., McClain, S., Jones, M., \& Johnson, S. (2012). A preliminary investigation of academic disidentification, racial identity, and academic achievement among African American adolescents. The High School Journal, 95, 54-68.

[5] Sidiropoulou-Dimakakou, D. (2009). Career Assessment. Athens: Metaixmio (In Greek).

[6] Galles, J. A., \& Lenz, J. G. (2013). Relationships among career thoughts, vocational identity, and calling: Implications for practice. The Career Development Quarterly, 61, 240-248.

[7] Reardon, R. C., \& Bertoch, S. C. (2010). Student motivation and program participation. Journal of College Student Development, 51, 716-722.

[8] Reardon, R. C., Lenz, J. G., Sampson, J. P., Jr., \& Peterson, G. W. (2017). Career development and planning: A comprehensive approach (5th ed.). Dubuque, IA: Kendall Hunt.

[9] Reardon, R. C., Melvin, B., McCain, M-C., Peterson, G. W., \& Bowman, J. (2015). An academic career course as a factor in college graduation. Journal of College Student Retention, 17(3), 336-350.

[10] Sampson, J. P., Jr., McClain, M-C., Musch, E., \& Reardon, R. C. (2013). Factors affecting readiness to benefit from career interventions. The Career Development Quarterly, 61, 98-109. doi:10.1002/j.21610045.2013.00040.x.

[11] Walker, J. V., III, \& Peterson, G. W. (2012). Career thoughts, indecision, and depression: Implications for mental health assessment in career counseling. Journal of Career Assessment, 20, 497-506. Doi: $10.1177 / 1069072712450010$.

[12] Yong, A. G., \& Pearce, S. (2013). A beginner's guide to factor analysis: Focusing on exploratory factor analysis. Tutorials in Quantitative Methods for Psychology, 9, 79-94.

[13] Sampson, J. P., Jr., Reardon, R. C., Peterson, G. W., \& Lenz, J. G. (2004). Career counseling and services: A cognitive information processing approach. Pacific Grove, CA: Brooks/Cole.

[14] https://www.interactiontalks.com/developing-decision-making-skills-high-school-students/;Last Accessed: $22^{\text {nd }}$ March 2018.

[15] https://www2.ed.gov/about/offices/list/ovae/pi/cte/guidcoun2.html; Last Accessed: $22^{\text {nd }}$ March 2018.

[16] Vanessa F. Freeman, Janet G. Lenz et al.; “Career Course Impact on College Students' Career Decision and Affective States; VISTAS Online; 703-823-9800 x281, 800-347-6647 x281.

\section{AUTHOR'S BIOGRAPHY}

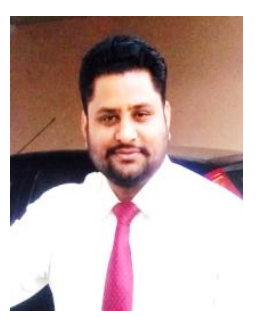

Dr. Gagandeep Jagdev, is a faculty member in Dept. of Computer Science, Punjabi University Guru Kashi College, Damdama Sahib (PB). His total teaching experience is above 11 years and has 123 international and national publications in reputed journals and conferences to his credit. $\mathrm{He}$ is also a member of editorial board of several international peer-reviewed journals and has been active Technical Program Committee member of several international and national conferences conducted by renowned universities and academic institutions. His field of expertise is Big Data, ANN, Biometrics, RFID, Cloud Computing, Cryptography, and VANETS.

Citation: Ranbir Singh \& Dr. Gagandeep Jagdev, (2018)" Constructive and Technical Aspects of Career Decision Making for Senior Secondary Students", International Journal of Research Studies in Computer Science and Engineering (IJRSCSE), 5(2), pp.1-6. DOI:http://dx.doi.org/10.20431/2349-4859.0502001

Copyright: (C) 2018 Ranbir Singh \& Dr. Gagandeep Jagdev, This is an open-access article distributed under the terms of the Creative Commons Attribution License, which permits unrestricted use, distribution, and reproduction in any medium, provided the original author and source are credited. 